\title{
ASSESSMENT OF LEVEL OF FINANCIAL LITERACY AMONG THE COLLEGE STUDENTS IN BHUTAN
}

\author{
Harilal Bhattarai ${ }^{1}$ and Gagan Mongar $^{2}$ \\ ${ }^{1}$ Sr. Analyst, Druk Holding and Investments Limited. \\ ${ }^{2}$ Lecturer Royal Thimphu College \\ http://dx.doi.org/10.38193/IJRCMS.2021.3411
}

\begin{abstract}
This study on the assessment of level of financial literacy among the college students in Bhutan was conducted taking a sample of 1,085 students from across several colleges in Bhutan offering bachelor's degree programs. The students from different degree programs broadly categorized here as management students and non-management students took part in the survey. There were 584 (54\%) management students and 501(46\%) students enrolled in other degree programs. The overall financial literacy index was built using the composite mean of the three dimensions; financial behaviour, financial attitude and financial knowledge. The overall financial literacy index is 2.1. This shows that the level of financial literacy among college students in Bhutan is low. Student's score on financial numeracy was even lower (1.8).
\end{abstract}

Majority of the students reported that they learnt about managing money mostly from friends (25.6\%), school $(21.8 \%)$, books $(21.4 \%)$, internet $(20.8 \%)$ and least from life experience $(4.4 \%)$ and parents $(4.8 \%)$. It could also be true that parents mandate their child to concentrate on study and not to be bothered by the financial matters of the family. It also notes that children are hardly involved in family financial decisions.

Recording and review of the everyday financial transaction is given least importance. Majority of the students $(57.8 \%)$ reported that they don't keep record of their financial transactions. About 38\% maintain minimal record. Only $3.8 \%$ of respondents reported they keep detailed record of their everyday financial transactions. Record keeping is also the least (9.6\%) things they learn from home while growing up. In regard to spending behaviour, only $8.2 \%$ reported that they are very economical in terms of their spending, while $36.0 \%$ reported that they are somewhat economical and majority $(55.8 \%)$ are spendthrift.

Contrast to the findings of Santini, Laderia, Mette and Ponchio (Santini, F.D.O., Ladeira, W.J., Mette, F.M.B. and Ponchio, M.C., 2019) no significant variations on the financial behavior between the gender and course they are enrolled in. In terms of financial numeracy, management students seem to be better than the non-management students $t(1075)=9.305, \mathrm{p}<0.05$. 
Students have fair understanding on banking and interest rates in Bhutan (3.5) but least aware of the insurance, its importance and risk diversification (2.9).

KEYWORDS: financial literacy, college students, colleges in Bhutan, financial knowledge, financial behavior, financial attitudes.

\section{INTRODUCTION}

Financial literacy has gained significant attention among many countries around the world. The importance of the financial literacy has become even more important with the rapid development and sophistication of the financial structure, financial regulations and financial products and services available in the evolving financial market. Proportionately the decision on the financial activities has become more complex.

The lack of financial knowledge limits the ability of making good financial decision (Chen \& Volpe, 1998) and invites host of personal problems in the family (Furtuna, 2008). Given its importance many countries have introduced the financial literacy in the formal educational curriculum. There are considerable amount of research and literature measuring the level of financial literacy in American and European nations and formulation of appropriate policies that enhance the financial well-being of its citizens, but not much has been done in the developing nations. Few researchers and academician have attempted to measure or assess the level of financial literacy among the young adults and university/college students in developing countries. However, none has attempted to conduct such research on the level of financial literacy among the college students in Bhutan. Apart from few discussions on financial literacy in general population in Royal Monetary Authority of Bhutan (RMA) Financial Literacy Strategy 2018-2023, resources in this area are very scarce in Bhutan. It must be appreciated to note that RMA emphasis on promotion of the financial literacy and engage youth in financial literacy through introduction of financial literacy in formal education curriculum and extracurricular activities.

Researches such as this is important to provide the timely policy intervention and in framing targeted strategies and approaches to promote the financial literacy among the younger citizen for their financial well-beings in the near future. The financial well-being is understood as "a state of being wherein a person can fully meet current and ongoing financial obligations, can feel secure in their financial future, and is able to make choices that allow them to enjoy life" (Consumer Financial Protection Bureau, 2017)

In order to assess the financial literacy of the college students in Bhutan, it may necessitate to understand a bit about the education system, youth literacy and the national strategies for the youth financial literacy. 


\section{Education in Bhutan}

The Royal Government of Bhutan $(\mathrm{RGoB})$ provides free education up to pre-university grade (i.e class XII). The government scholarship for the graduate students depends on a preset-criteria in students' academic performance. Those students meeting the eligibility criteria receives the state sponsorship to continue their education in government or few private colleges in Bhutan and abroad. However, the intake on the government scholarship remains almost same or with little increment over the years compared to the unproportionate increase in the enrollment every year. The remaining students who do not achieve the level of academic grades for state sponsorship in class twelve (12) usually enroll through self-financing.

Unlike in developed countries the regular student pursuing their studies in colleges in Bhutan through self-financing are mostly depended on the financial support from their parents/relatives. In a move to facilitate higher education for economically disadvantaged students' government has instituted a tertiary education loan scheme since 2014.

So far, there is no financial literacy curriculum into the formal education system in Bhutan. Although the subjects related to business and finance are taught at High school levels, often this does not cover the financial literacy or wholesomely promote the financial literacy among the younger adults.

\section{National Financial Literacy Strategy}

The Royal Monetary Authority (RMA) of Bhutan has launched the National Financial Literacy Strategy (NFLS) 2020. This strategy aims at strengthening financial capabilities and empower all Bhutanese towards greater financial inclusion. The RMA is spearheading the financial inclusion and financial literacy in the country. The RMA has set up a separate unit dedicated to spearhead all financial literacy activity in Bhutan. 'Educating the next generation' is one of the four strategic priorities of the NFLS. Among the many core action under this priority, and particularly to promote financial literacy among the youth, RMA is developing a Ministry of Education-endorsed curriculum and promote a curriculum-based approach to teaching financial literacy in primary and secondary schools and engage youth in financial literacy through extra-curricular activities.

\section{Financial Literacy in Bhutan}

The data and information on the level of financial literacy in Bhutan is rarely found. There is no such study done to examine the level financial literacy of the college students. Market Development Program in Bhutan by ADB reports that the financial literacy in Bhutan is low (ADB, 2019). The NLFS report notes that most Bhutanese do not save to invest, build income-generating assets for longterm planning, or even keep track of expenses and budgeting. Even most of the civil servants rely solely on their pension for their retired life. Insurance services are perceived as expenses and not 
investments to protect against risk (RMA). So, looking at the financial behavior, discipline, attitude and choices of the financial products and services proves to some extend that the financial literacy is low in the country.

The financial literacy among the rural population is expected to be even lower given their small and irregular saving, high cost of serving distant location for banks, poor access to banks, lack of access to formal remittances, low level of formal education and inadequate financial knowledge. It is also reported that people in the rural areas prefers to keep their saving as ready cash (ADB, 2019)

\section{Youth Financial literacy in Bhutan}

There is no study undertaken to understand the financial literacy among the youth in Bhutan. Most of the financial needs of the youth are taken care by their parents/elders. Perhaps with fairly simple financial structure and limited financial products and services youth financial literacy has not been discussed much in Bhutan. However, trend is changing, there is a growing trend of youth going for studies abroad especially in Australia, Canada, Japan etc. were most of them manages their own finances for university fees, personnel expenses and for their future and increasing use of credit facilities. It is essential that financial literacy is imparted early in their life. It is beneficial to provide financial education before individuals engage in financial contracts and before they start making financial decisions (Garg \& Singh, 2018) and preparedness for retirement (Lusardi \& Mitchel, 2006). It is reasonable to assume that classes taken during the senior year, when students have either attained or are about to attain legal adulthood and have taken on some of the financial responsibilities of adults, would be more relevant and interesting than if taken when a student was 15 or 16 years old (Klein, 2009).

The importance of development of the financial literacy has been already perceived by government of Bhutan, it is evident from the RMA's action on development and implementation of the National Literacy Strategy document and prioritizing the "Educating the next generation' as one of its core priorities. It also notes that interventions to educate and instill the right values in the young are easier than changing the financial habits of an older generation. (RMA, 2019-2023). Several banks have saving accounts for minors, the piggy bank account in Bhutan National Bank is a good example. Objectives and Significance of the Study

Research Objective: To understand the level of financial literacy among the college students in Bhutan.

Significance: The literature on the financial literacy in Bhutan is very scarce. Further, there is no research carried out to measure the level of financial literacy among the college students, and it is first of its kind in Bhutan. Therefore, it is expected to provide some useful insight in relevant intervention 
in national policies and taking appropriate targeted approach in promoting financial literacy among the younger generation. Understanding the financial literacy among the college students in particular is even more important from policy perspectives as many of these students would be taking up jobs and managing their finances on their own for their long-term financial well-being.

\section{Literature Review}

Different researchers, often have different definitions for the term financial literacy. Definitions for financial literacy differ in context as well as in source (Hung H.C, 2009). The term such as financial education, financial capability, financial knowledge etc. often causes some confusions to the consumers, (Cohen, 2011). However, they often seek to convey in whole or in part the same meaning of financial literacy. These are sometimes defined in context to the financial market structure, regulation and sophistication of the financial products and services in the particular economy.

\section{Definition of financial literacy}

John Adams seems to be the first man to coin the term Financial Literacy and one of the first person who saw the need to promote the financial education in the US (UNSGSA, 2016).

The existing conceptual definition speaks to ability, knowledge and skills, but makes no attempt to articulate what aspects of money management actually constitute a person's financial literacy The existing conceptual definition speaks to ability, knowledge and skills, but makes no attempt to articulate what aspects of money management actually constitute a person's financial literacy The existing conceptual definition speaks to ability, knowledge and skills, but makes no attempt to articulate what aspects of money management actually constitute a person's financial literacy Financial literacy describes the skills, knowledge and tools that equip people to make individual financial decisions and actions to attain their goals; this may also be known as financial capability, especially when paired with access to financial products and services (U.S. National Strategy for Financial Literacy, 2020).

Noctor (1992) defines financial literacy as the individual's capability to make complete verdicts and to take pronouncements that are effective with regards to the use and management of her/his money (Noctor, 1992). Lusardi (2008) defines financial literacy as the knowledge of basic financial concepts, such as the working of interest compounding, the difference between nominal and real values, and the basics of risk diversification (Lusardi A., 2008).

Financial capability is also a synonymous term to financial literacy, the term was introduced by the UK Financial services Authority (FSA). Royal Monetary of Bhutan (RMA) defines it as a combination of financial knowledge, skills, attitude and behavior that allows an individual to make rational, informed and sound financial decisions. Similarly, the Organization for Economic Co-operation and 
Development (OECD) defines financial literacy as not only the knowledge and understanding of financial concepts and risks but also the skills, motivation, and confidence to apply such knowledge and understanding in order to make effective decisions across a range of financial contexts, to improve the financial well-being of individuals and society, and to enable participation in economic life. Thus, the definition of financial literacy is not limited to financial knowledge and skills only but also include financial behavior such as motivation and confidence.

\section{Importance of Financial Literacy}

There is no denial that the financial literacy is very important in everyday life. The developed nations like America has felt the importance of the literacy long time ago. The history dates back from times of Benjamin Franklin sometimes around 1737, who gave a bit of financial advice "A penny saved is two pence clear." in his column titled "Hints For Those That Would Be Rich."

We have witnessed the rapid development in the financial arena and how crucial it is to manage the finance in everyday life for the financial well-being of the individual. Financial literacy has become an indispensable tool for the economic well-being of the individual. Furthermore, financial instruments have become increasingly complex and individuals are presented with new and ever-more sophisticated financial products (Lusardi, A, 2008). Policymakers around the world have expressed deep concern about widespread gaps in financial knowledge and various measure have been devised to make its citizen financially literate. Given the complexity of current financial instruments and the financial decisions required in everyday life, from comparing credit card offerings, to choosing methods of payments, to deciding how much to save, where to invest, and how to get the best loan, individuals need to know how to read and write financially (Lusardi, A, 2008). A research done in America finds that many individuals lack a basic understanding of how to control debt, how to save and how to plan a solid financial future (Furtuna, 2008).

Sandra and Carolyn (2002), report that with the technological, market, and legislative changes have resulted in a more complex financial services industry that requires consumers to be more actively involved in managing their finances (Braunstein \& Welch, 2002). It is noted that low level of financial knowledge would limit the ability of making good financial decision (Chen \& Volpe, 1998). Financial illiteracy has long been recognized as a major problem in poor households and communities (Engelbrecht, 2008). The poor financial decision invites many problems in the family too. Financial problems are one of the primary reasons for divorce (Furtuna, 2008).

There is no option to avoid what we do not know, such attitude in managing every day finance would throw our life in utter financial ruins.

\section{Measuring Level of Financial Literacy}


There is no any standard framework for the measurement of the financial literacy. Building a standard instrument for measure of financial literacy is obviously difficult given the levels of economic development, structure of financial systems, regulations and diversity of financial products and service etc. It should certainly be build based on the level of economies and financial structure, financial regulations and diversity of the financial products and services available in that economy. The question of financial literacy model is penitently linked to the level of financial market development and social demographics of place of interest for the research (Juma Buhimila Mabula, 2018). It depends on the complexity of the financial market structure, financial regulations and product/services. The structure of financial sector and the availability of financial products automatically engages individual and firm into transactional networks forcing them into a learning stream hence automatically becomes literate (Ping).

In order to measure the level of financial literacy it is important that the instruments are designed as per the definition of the financial literacy that fits precisely in context to that economy. However, many studies in process has deviated from the very definition of the financial literacy or in context to that level of economy where the studies have focused. Juma and Han (2018) has also found that there is a need to interpret financial literacy in developing economies in line with the features characterizing these countries economy and their level of financial sector development (Juma Buhimila Mabula, 2018). Remund and David (2010) notes that existing conceptual definition speaks of ability, knowledge and skills, but makes no attempt to articulate what aspects of money management actually constitute a person's financial literacy.

Therefore, this study measures the level of financial literacy among the college students in Bhutan in line with the definition provided by the Royal Monetary of Bhutan as defined above.

\section{Financial Literacy in some developing economies}

Considerable amount of studies on the youth financial literacy has been conducted in the developed economies but not much have been done in the developing economies. Even in the developed economies the level of financial literacy is found to be low (Baverly \& Burkhalter, 2005). A study conducted with 522 university students from 13 different higher education institutions in Estonia revealed that the level of financial literacy of student is low (Mändmaa, 2019). Similarly, Kiliyanni \& Latheef (2018) in their study revealed low level of financial literacy among the educated young adult (Kiliyanni \& Sivaraman, 2018). While, Sri Lanka showed that financial literacy level of majority of the undergraduates of the three universities is at a moderate level (Edirisinghe, Keerthipala, \& Amarasinghe, 2017). This study considered the knowledge on money management, savings, investment, credit and insurance has been considered to measure the financial literacy level of the undergrad students in Sri Lanka. 
The University students in Nepal are found to be knowledgeable in basic level of finance. Knowledge of numeracy was found to be highest while banking, inflation and share market was found to be medium, and low in credit, taxes, financial statement and insurance (Thapa \& Nepal, 2015). A similar study conducted in Ghana showed that little more than half of the graduates were financially literate, and male students were found to be financially knowledgeable compared to the female students (Oseifuah \& Gyekye, 2018). Lusardi, Mitchell and Curto (2010) also confirm low levels of financial literacy of South African young adults. It is found that fewer than a third possessed basic understanding of interest rates, inflation, and risk diversification (Lusardi et al., 2010). Lusardi (2008) notes that there are sharp gender differences in financial literacy, with women displaying a lower level of knowledge than men, particularly with regard to risk diversification.

\section{METHODOLOGY}

\section{Research Problem}

The financial need of the college students is Bhutan is mostly met by the government /parents/sponsors. Graduate students often do not feel the need to understand the management of their finance. Parents/elders usually prefers not to give the burden of managing finance to the students instead strive them to better preform in their academics.

Research Design: It's a mixed of descriptive and quasi-experimental research that describe the level of the financial literacy among the college students in Bhutan and checks the relationship between certain applicable variables. A conceptual design for the research and analysis is designed based on the RMA's definition of financial literacy to guide the systematic approach in identifying parameters and perform statistical procedure to achieve the intended objective of the research.

Sampling: This research focused college students since most of them will be pursuing a career after their graduation. There are more than 8,000 students pursuing various degrees courses in 10 different colleges under Royal University of Bhutan.

Data Collection: Data on financial literacy among the college students were collected using an online survey form. A set of survey questionnaire covering all the essential parameters and items to adequately measure the level of financial literacy was designed using the online survey portals. The questionnaire also collected the demographic and economic data of the students and parents.

Questionnaire Design: Considering the similarities of the socio-demographic, economic and financial structure of Bhutan and Nepal, the questionnaire for the survey is adopted from financial literacy study conducted on the college students in Nepal (Thapa \& Nepal, 2015) with little modification suitable to the Bhutanese context. Questionnaire also retains questions by Lusardi and 
Mitchell (2006, 2008) which was originally designed for the 2004 HRS.

The three main dimensions used for the construction of the financial literacy index, that formed the crux of the questionnaire design are defined as below:

- $\quad$ Financial Behaviour - student's action with respect to the money management

- $\quad$ Financial Attitude -student's state of mind about money or their finances

- $\quad$ Financial Knowledge - student's understanding of money and the basic financial concepts and skills, and capability to manage money in different usage.

Data Analysis: Data were analyzed using the statistical software (SPSS and Excel). Data cleaning for incomplete sets, and data reliability was done using Cronbach's alpha. The descriptive and inferential statistical procedure were used depending on the experimental parameters/variables required for the desirable output in fulfilling the research objective. It entailed the testing of the hypothesis for comparing and contrasting against the similar research findings in other literatures.

Research Ethic: Research ethic is a necessary part of any research. The participation of the respondent was strictly volunteer. Consent on participation of students in survey was also sought from the respective colleges through emails to deans of the colleges. The information gathered has been maintained strictly confidential and used for the intended purpose only. In order to incentivizes for their time, the authors have provided Nu. 99 internet data packages to randomly selected 5 students who participated on online survey.

\section{Model - Composite Mean}

The financial literacy index $=\mathrm{m} 1+\mathrm{m} 2+\mathrm{m} 3 \ldots / \mathrm{N}$

Where $\mathrm{m} 1, \mathrm{~m} 2, \mathrm{~m} 3 \ldots$ are mean scores of all dimensions and $\mathrm{N}=$ number of dimensions

\section{Analysis, Findings and Discussion}

Sample of 1,085 students from across different colleges in Bhutan took part in the online survey. There are $515(47 \%)$ males and $570(53 \%)$ females, of which $584(54 \%)$ are enrolled in management courses and $501(46 \%)$ from other degree courses. Majority are self-financed $(73 \%)$ and around $26 \%$ are under full government and other scholarship and just $1 \%$ are on some other partial scholarships. Majority $(66 \%)$ of the student's family monthly income falls under bracket of $\mathrm{Nu} .20,000$ to $\mathrm{Nu} .30,000$.

The index of the level of financial literacy was computed as the composite mean of latent variables; financial behaviour, financial attitude and financial knowledge.

The overall level of financial literacy among the college students in Bhutan is found to be very low with index of 2.2. The mean scores against these dimensions are; financial behaviour (1.8), financial 
attitude (2.4) financial knowledge (2.5).

Contrast to the findings of Santini, Laderia, Mette and Ponchio (Santini, F.D.O., Ladeira, W.J., Mette, F.M.B. and Ponchio, M.C., 2019) no significant variations on the financial behavior between the gender and course they are enrolled in. Similarly, no significant difference was noted between family income and overall score of students in these dimensions, $\mathrm{f}(3,1084)=.295, \mathrm{p}=.829$. However, $\mathrm{t}$ statistics $t(1084)=9.305, \mathrm{p}<0.05$ shows that management students seems to be better than the nonmanagement students in terms of financial numeracy (interest calculation, time value etc.)

Students have fair understanding on banking and interest rates in Bhutan (3.5) but not much understanding of insurance, its importance (2.9) and risk diversification.

When asked about their spending behaviour, only $8.2 \%$ reported that they are very economical in terms of their spending, while $36.0 \%$ reported that they are somewhat economical and majority $(55.8 \%)$ are quite spendthrift.

In terms of the influence majority reported that they learnt about managing money mostly from friends (25.6\%), school $(21.8 \%)$, books $(21.4 \%)$, internet $(20.8 \%)$ and least from life experience $(4.4 \%)$ and parents $(4.8 \%)$. It shows that parents hardly include their children in financial decisions. It could also be true that parents mandate their child to concentrate on study and not to be bothered by the financial matters of the family.

Recording of the everyday financial tractions is given the least importance. Majority of the students $(57.8 \%)$ reported that they don't keep record of their financial transactions. About 38\% maintain minimal record. Only $3.8 \%$ of respondents reported they keep detailed record of their everyday financial transactions. Record keeping $(9.6 \%)$ is also the least things they learn from home while growing up.

\section{Discussion of Issues Uncovered}

College students in Bhutan has very low level of financial literacy. It also finds that parents have low involvement in educating the children in financial matters.

Unlike other studies, this study does not show any significant relationship between financial behaviour, financial attitude, financial knowledge and the family income level of the students.

While the result shows the fair knowledge on banking and interest rates in Bhutan, majority of the students do not know about insurance, its importance and risk diversification. Student hardly keep record of their daily financial transactions. 
While students not only reports that they learn least on money management from parents, their involvement in the financial decision at home is also low (30\%). Therefore, it necessitates the parents to teach at home about the financial literacy to the children so that the children have sound knowledge of their financial matters to lead a financial stress-free life in their adulthood.

\section{Acknowledgement}

The authors would like to extend our sincere thanks to all the students who took part in the online survey, and the deans/faculties of the respective colleges for kindly forwarding the online survey link and encouraging the students to sincerely participate in the survey. We are equally thankful to many others who helped in reviewing, for critique and encouragement to publish this paper. Similarly, we would like to thank the publisher for publishing the paper without much delay in their journal.

\section{REFERENCES}

ADB. (2019). Proposed Programmatic Approach and Policy Based Loan for Subprogram 1 and Technical Assistance Grant Kingdom of Bhutan: Financial Market Development Program ADB 2019. ADB.

Baverly, S. G., \& Burkhalter, E. K. (2005). Improving the Financial Literacy and Practices of Youths. Retrieved from https://search.proquest.com/openview/fa57592a0387fc0e26f83eaab5dedd52/1?pqorigsite $=$ gscholar $\& \mathrm{cbl}=26011$

Braunstein, S. F., \& Welch, C. (2002). Financial literacy: an overview of practice, research, and policy. Federal Reserve Bulletin, Board of Governors of the Federal Reserve System (U.S.), 88, 445-457.

Carrington, Cole, R. A., \& J, S. (2017). Banking in Bhutan - An Assessment of Financial Sector Development in Bhutan. Research Gate.

Chen, H., \& Volpe, R. P. (1998). An Analysis of Personal Financial Literacy Among College Students. Financial Service Review.

Cohen, M. a. (2011). Financial Literacy: A step for Clients towards Financial Inclusion.

Consumer Financial Protection Bureau. (2017). p.6.

Curto, A. L. (2009). Financial Literacy Among the Young: Evidence and Implication for Consumer Policy. National Bureau of Economic Research.

Edirisinghe, C., Keerthipala, Y. M., \& Amarasinghe, A. R. (2017). Financial Literacy and Financial Behavior of Management Undergraduates of Sri Lanka. International Journal of Management and Applied Science,, olume-3(Issue-7 ).

Engelbrecht, L. (2008). The Scope of Financial Literacy Education: A Poverty Alleviation Tool in Social Work? Social Work/Maatskaplike Werk, 44(3), 252-262.

Furtuna, F. (2008). College Students' Personal Financial Literacy: Economic Impact and Public Policy Implications. Under Graduate Economic Review, 4(1).

Garg, N., \& Singh, S. (2018). Financial literacy among youth. International Journal of Social 
Economics, 45(1) (January, 2018), 173-186.

Hung H.C, K. S. (2009). a Capacitor of Behavioral Variation. J. Biol. Rhythms 24(3): 183--192. Juma Buhimila Mabula, H. D. (2018). Financial Literacy Position in Developing Economies: A Review of Studies and Open Issues. At Lantis Presss.

Kiliyanni, A. L., \& Sivaraman, S. (2018). A Predictive Model for Financial Literacy among the Educated Youth in Kerala, India. Journal of Social Service Research, Volume 44(Issue 4).

Klein, L. M. (2009). The Impact of Financial Literacy Education on Subsequent Financial Behavior. Association for Financial Counseling and Planning Education.

Lusardi, A. (2008). Financial Literacy: An Essential Toll for Informed Consumer Choice? National Bureau of Economic research.

Lusardi, A. (2008). Household Saving Behavior: The Role of Financial Literacy, Information, and Financial Education Programs.”. The George Washington University School of Business, NBER Working Paper No. 13824.

Lusardi, A., \& Mitchell, O. (2006). Financial Literacy and Retirement Preparedness: Evidence and Implications for Financial Education. Michigan Retirement Research Center.

Lusardi, A., Mitchell, O. S., \& Curto, V. (2009). Financial Literacy Among the Young: Evidence and Implications for Consumer Policy. National Bureau of Economic Research.

Mändmaa, S. (2019). Analyzing the factors influencing university students' financial literacy. International Journal for Innovation Education and Research, Vol:-7 (No-7).

Noctor, M. S. (1992). Financial Literacy: A Discussion of Concepts and Competences of Financial Literacy and Opportunities for its Introduction into Young People's Learning. Report prepared for the National Westminster Bank, National Foundation for Education Research, London.

Oseifuah, E., \& Gyekye, A. (2018). Financial Literacy among Undergraduate Students: Empirical Evidence from Ghana. Academy of Accounting and Financial Studies Journal.

Ping, J. B. (n.d.). Financial Literacy Position in Developing Economies: A Review of Studies and Open Issues. Atlantis Press.

Remund, D. L. (2010). Financial Literacy Explicated: The Case for a Clearer Defination in an Increasingly Complex Economy. The Journal of Consumer Affairs, 44.

RMA. (2019-2023). National financial literacy strategy. 2019-2013.

Thapa, B. S., \& Nepal, S. R. (2015). Financial Literacy in Nepal: A Survey Analysis from College Students. NRB Economic Review, 27(1), 49-74.

Santini, F.D.O., Ladeira, W.J., Mette, F.M.B. and Ponchio, M.C. (2019), "The antecedents and consequences of financial literacy: a meta-analysis", International Journal of Bank Marketing, Vol. 37 No. 6, pp. 1462-1479

(2020). U.S. National Strategy for Financial Literacy. U.S. Financial Literacy and Education Commission.

UNSGSA. (2016). Strengthening the Roots of Financial Resilience in Financial Education. Retrieved from UNSGSA: https://www.unsgsa.org/speeches/strengthening-roots-financial-resilience-financial- 
International Journal of Research in Commerce and Management Studies

ISSN 2582-2292

Vol. 3, No. 04 July-Aug; 2021

education 